\title{
KOMPONEN INTERVENSI DALAM PROSES KEPERAWATAN
}

\author{
ANGEL OKTAVIA PURBA / 181101099 \\ angeloktavia013@gmail.com
}

\begin{abstract}
ABSTRAK
Perencanan adalah pengembangan strategi desain untuk mencegah, mengurangi, dan mengatasi masalah-masalah yang diidentifikasi dalam diagnosis keperawatan. Tujuan dari penulisan ini adalah untuk mengetahui defenisi dan bagaimana proses keperawatan tahap perencanaan. Mengetahui tujuan dari perencanaan keperawatan dan apa saja kegiatan yang harus dilakukan perawat dalam tahap perencanaan. Metode penulisan ini adalah Literature Riview, dimana ini menganalisis artikel yang relevan dan berfokus pada tema yaitu pelaksanaan tahap perencanaan dalam proses keperawatan. Hasil Berdasarkan pencarian literature didapatkan defenisi perencanaan dalam proses keperawatan, tujuan dari tahap perencanaan, mengetahui apa saja kegiatan yang harus dilakukan perawat dalam tahap perencanaan. Selain itu juga berdasarkan pencarian literature juga di dapatkan bagaimana pelaksanaan tahap perencanaan.
\end{abstract}

Kata Kunci : Proses keperawatan, Perencanaan dalam proses keperawatan, kegiatan dalam tahap perencanaan.

\section{LATAR BELAKANG}

Dalam keperawatan terdapat proses keperawatan yang menjadi pedoman perawat dalam memecahkan masalah klien. Proses keperawatan adalah suatu pendekatan dalam pemecahan masalah, sehingga perawat dapat merencanakan dan memberikan asuhan keperawatan (Potter and Perry, 1997). Proses keperawatan akan sangat membantu perawat dalam merencanakan asuhan keperawatan yang tepat dan berkualitas. Perawat sebagai suatu profesi merupakan bagian dari tim kesehatan yang bertanggungjawab membantu klien sebagai individu, keluarga, dan masyarakat baik dalam kondisi sehat maupun sakit. Seiring perkembangan keperawatan, keilmuan dalam praktik Keperawatan pun turut berkembang. Berbagai penelitian berdasarkan fenomena yang ada di dunia pelayanan keperawatan dilakukan. Penerapan proses keperawatan dalam asuhan keperawatan untuk klien merupakan salah satu wujud tanggung jawab dan tanggung gugat perawat terhadap klien. 
Pada akhirnya, penerapan proses keperawatan ini akan meningkatkan kualitas layanan keperawatan kepada kllien. Tahap proses keperawatan setelah Diagnosa yaitu tahap Perencanaan dimana,perencanaaa merupan unsur yang penting dalam keperawatan, oleh karena itu perlu mendapatkan perhatian yang sungguhsungguuh dalam pelaksanaanya. Setiap perawat harus memahami dengan sungguh konsep-konsep perencanaan yang meliputi penngertian, tujuan, keuntungan/kerugian, ciri-ciri perencanaan, dan kriteria-kriteria perencanaan yang efektif. Sebagai aplikasinya perlu dipahami pula perencanaan program dalam keperawatan/kesehatan dan perencanaan kebutuhan tenaga perawatan di Rumah Sakit.

\section{TUJUAN}

Tujuan dari penulisan ini adalah untuk mengetahui defenisi dan bagaimana proses keperawatan tahap perencanaan. Mengetahui tujuan dari perencanaan keperawatan dan apa saja kegiatan yang harus dilakukan perawat dalam tahap perencanaan.

\section{METODE}

Metode penulisan ini adalah Literature Riview, dimana ini menganalisis artikel yang relevan dan berfokus pada tema yaitu pelaksanaan tahap perencanaan dalam proses keperawatan. Adapun sumber yang digunakan dalam literature ini menggunakan sumber dari buku teks, jurnal dengan memasukan kata kunci pelaksanaan tahap Perencanaan dalam proses keperawatan. Adapun jurnal yang saya yang digunakan merupakan jurnal yang diiterbitkan pada 10 tahun terakhir.

\section{HASIL}

Berdasarkan pencarian literature didapatkan defenisi perencanaan dalam proses keperawatan, tujuan dari tahap perencanaan, mengetahui apa saja kegiatan yang harus dilakukan perawat dalam tahap perencanaan. Selain itu juga berdasarkan pencarian literature juga di dapatkan bagaimana pelaksanaan tahap perencanaan.

\section{PEMBAHASAN}

Perencanan adalah pengembangan strategi desain untuk mencegah, mengurangi, dan mengatasi masalahmasalah yang diidentifikasi dalam diagnosis keperawatan. Desain 
perencanaan menggambarkan sejauh mana perawat mampu menetapkan cara menyelesaikan masalah dengan efektiif dan efisien. Sedangkan menurut Levey dan loomba, perencanaan itu adalah suatu proses penganalisan dan pemahaman dari satu sistem, merumskan tujuan umum dan tujuan khusu,memperkirakan kemampuan yang dimiliki, menguraikan kemungkinan rencana kerja yang dapat dilakukan untuk mencapai tujuan umum dan tujuan khusus tersebut, menganalisi efektifitas dari berbagai rencana kerja ini,memiliki satu diantaranya yang dipandang paling baik,menyususn perincian dari rencana kerja terpilih secara lengkap agar dapat dilaksanakan, dan mengikatnya dalam suatu sistem pengawasan yang terus menerus dalam rangka dapat dicapainya hubungan optimal antara rencana kerja dengan sistem yang ada. Adapun tujuan dari perencanaan keperawatan terdiri dari 2 yaitu : 1. Tujuan administrasi, administrative mengidentifikasi focus keperawatan. Fokus keperawatan. Fokus intervensi keperawatan dapat diidentifikasi melalui rencana keperrawatan yang disusun. Rencana keperawatan yang bersifat promotif, preventif, kuratif dan rehabilitatif merupakan suatu rangkaian rencana keperawatan yang disusun berdasarkan masalah yang terjadi. 2.Tujuan klinik, merupakan penunjuk dalam pelaksanaan tindakan keperawatan. Tindakan keperawatan selalu beredoman pada perencanaan yang terlah dibuat, tidak ada satu tindakan pun yang keluar dari perencanaan. Semua rencana yang telah ditetapkan merupakan pulihan yang rasional/ilmiah dan betul-betul diperlukan untuk mengatasi masalah yang terjadi.

Adapun kegitan yang dilakukan dalam tahap perencanaan yaitu :

1.Menentukan prioritas masalah keperawatan. Kegiatan pertama yang dilakukan dalam perencanaaan keperawatan adalah menentukan prioritas masalah keperawatan. Keggiatan ini dimaksudkan untuk menentukan masalah yang akan menjadi skala prioritas untuk diselesaikan atau diatasi terlebih dahulu.

Beberapa teknik membuat skala prioritas antara lain sebagai berikut : a. Standart V: standart asuhan keperawatan. Dalam standart v asuhan keperawatan, prioritas dititik beratkan pada masalah yang mengancam kehidupan. Skala prioritas yang 
ditentukan dengan konsep 1. Prioritas pertama, masalah yang mengancam kehidupan;. 2) Prioritas kedua, masalah yang mengancam kesehatan;. 3) Prioritas ketigaa, masalah yang mempengaruhi perilaku kehidupan.

b. Depkes RI, 1992: pedoman asuhan keperawatan, Pedoman asuhan keperawatan menetapkan hal sebagai berikut : 1).Prioritas pertama diberikan pada masalah actual;. 2). Prioritas kedua pada masalah potensial.

c. Hierarki Maslow. Hierarki membuat lima hierarki kebutuhan dasar manusia. Hierarki yang menjadi prioritas pemenuhan pada kebutuuhan dasar yang bersifat fisiologis. Kebutuhan ini meliputi oksigenasi, cairan dan elektrolit, eliminasi, nutrisi, istirahat tidur, aktivitas dan mobilisasi, seksualitas dan lain-lain. Prioritas kedua adalah rasa aman dan nyaman, dilanjutkan dengan cinta kasih dan saying pad prioritas ketiga. Proritas berikutnya adalah kebutuhan harga diri dan aktualisasi diri.

d. Pendekatan Body System (B1-B6). Pendekatan ini menitikberatkan pada fungsi tubuh. Dalam hal ini fungsi Breathing (pernafasan) menjadi yang pertama dan utama karena gangguan pada fungsi ini dapat mengancam jiwa klien. Kemudian untuk pendekatan kedua adalah Blood ( darah/ sirkulasi darah, pendekatan ketiga Brain (kesadaran), pendekatan keempat yaitu Bladder (perkemihan), Pendekatan kelima yaitu Bowel (pencernaan), dan pendekatan keenam adalah Bone( meliputi kulit, selaut lender,dan tulang).

Setelah menentukan prioritas masalah keperawatan maka lang kah selanjutnya adalah Menetapkan tujuan dan kriteria hasil, tujuan yang dimaksud adalah tujuan yang ditetapkan yang merupakan perubahan perilaku pasien yang diharapkan oleh perawat setelah tindakan keperawatan berhasil dilakukan. Kriteria tujuan yang dirumuskan harus harus dirumuskan secara singkat dan jelas, rumusan disusun berdasarkan diagnosis keperawatan, spesifik,dapat diukur/ diobservasi, realistis atau dapat dicapai, terdiri dari subjek, perilaku, kondisi,dan kriteria tujuan. Selanjutnya bagaimana cara menentukan tujuan rencana asuhan keperawatan?

Dalam merumuskan tujuan perawat harus ada komponen-komponen sebagai berikut

1)Formulasi pertama

$\mathrm{S}+\mathrm{P}+\mathrm{H}+\mathrm{K}+\mathrm{T}$ 
S : subjek,siapa yang mencapai tujuan

P : predikat, kata kerja yang diukur, perawat harus mampu tulis sebelum kata kerja mampu.

$\mathrm{H}$ : Hasil, respond fisiologi yang perawat harapkan dari klien terhadap intervensi.

$\mathrm{K}$ : kriteria, mengukur kemajuan klien dalam mencapai hasil.

$\mathrm{T}$ : timer, target waktu, priode tertentu untuk mencapai kriteria hasil.

2) Formulasi kedua

$\mathrm{S}+\mathrm{P}+\mathrm{K}$

S : subjek

P : predikat/perilaku yang diharapkan setelah klien mampu mencapai tujuan.

$\mathrm{K}$ : kriteria kondisi pencapain tujuan

3) Formulasi ketiga

$\mathrm{S}+\mathrm{M}+\mathrm{A}+\mathrm{R}+\mathrm{T}+\mathrm{T}$

S : spesifik, berfokus pada pasien, singkat dan jelas.

$\mathrm{M}$ : measurable, dapat diukur.

A : achievable, realistis.

$\mathrm{R}$ : reasonable, ditentukan oleh perawat dank lien.

T: time, kontrak waktu.
Dari tiga formulasi rumusan masalah diatas, dapat diambil kesimpulan bahwa dalam menetapkan tujuan harus ada tiga unsur sebagai berikut:

1.Subjek, yaitu orang yang akan mencapai tujuan.

2.Predikat, yaitu perilaku yang diingnkan berubah dari klien setelah tujuan tercapai.

3.Kriteria/kondisi, yaitu kriteria/kondisi yang menunjukkan kapan atau pada saat bagaimana perilaku telah mencapai tujuan yang diinginkan.

Adapun contoh-contoh tujuan antara lain:

1.Nyeri klien berkurang dalam waktu 1x24jam.

2. Integritas kulit tetap utuh selama klien tidak sadar.

3.Klien mampu berjalan sejauh 15 meter dengan bantuan 1 orang perawat dalam waktu 4x24 jam.

4.Klien dapat beradaptasi terhadap nyeri selama proses persalinan.

5.Tolenransi aktivitas klien meningkat dalam waktu $2 \times 24$ jam. 
Langkah-langkah yang dilakukan setelah menentukan tujuan dan kriteria hasil yaitu Menetapkan kriteria hasil yang merupakan indicator keberhasilan dari tujuan yang telah ditetapkan. Kriteria hasil berorientasi pada masalah dan kemungkinan penyebab dan merujuk pad simtom dan meliputi empat aspek yaitu :

a . Aspek kognitif, contohnya:

1.Menyebutkan perawatan diabet nonfarmakologis dengan benar;.

2. Menyebutkan tiga penanganan pertama diare dengan tepat.

b. Aspek efektif, contohnya:

1. Mengungkapakan perasaan kecemasan terbuka;. 2. Menyatakan keinginan untuk berhubungan dengan staf.

c.Aspek psikomotor, contohnya: 1. Mampu mendemontrasikan perawatan tali pusar;. 2.Mampu mendemontrasikan cara perawatan payudara postpartum dengan benar.

d.Aspek perubahan fungsi tubuh, contohnya : 1 .Volume cairan seimbang 2000cc/hari;. 2.Wajah relaks;. 3.Nadi 60-100 kali/menit.

Kemudian langkah selanjutnya setelah menetapkan kriteria hasil yaitu
Merumuskan rencana tindakan keperawatan. Tipe rencana tindakan keperawatan terdiri dari 4 yaitu :

1.Diagnostik/observasi, rencana tindakan diagnostic adalah rencana tindakan untuk mengkaji atau melakukan observasi terhadap kemajuan klien dengan pemantauan secara langsung yang dilakukan secara continue. Contoh dari tindakan keperawtan diagnostic : Lakukan observasi terhadap tekanan darah,suhu, nadi dan respirasi setiap 8 jam.

2.Terapeutik/nursing treatment, rencana tindakan keperawatan teraupetik adalah rencana tindakan yang ditetapkan untuk mengurangi, memperbaiki, dan mencegah perluasan masalah. Contoh dari tindakan keperawatan terapeutik : Lakukan ROM pasif pada kaki klien 4xsehari.

3.Penyuluhan/ Health education (pendidikan kesehatan. Rencana tindakan keperawatan yang berbentuk pendidikan kesehatan adalah rencana tindakan yang ditetapkan bertujuan untuk meningkatkan perawatan diri klien dengan penekanan pada partisipasi klien dengan penekanan pada partisifasi klien untuk bertanggung jawab dalam perawatn diri, terutama untuk perawatn 
dirumah. Contoh rencana tindakan keperawatan penyuluhan : jelaskan pada keluarga tentang perawatan anak demam di rumah, dll.

\section{Rujukan/Kolaborasi/medical}

treatment. Rencana kolaboratif ini disesuaikan dengan masalah yang terjadi. Masalah yang bersifat kognitif,afektif,dan psikomotor mungkin tidak memerlukan tindakan medis. Namun untuk masalah yang berhungungan dengan perubahan fungsi tubuh, sering memerlukan rencana kolaboratif. Contoh rencana tindakan keperawatan kolaboratif : Lksanakan hasil kolaboratif pemberian paracetamol $3 \times 500 \mathrm{mg} / \mathrm{hari}, \mathrm{dll}$.

Setelah merumuskan rencana tindakan keperawatan maka langkah selanjutnya adalah menetapkan rasional rencana tindakan keperawatan. Rasional rencana tindakan keperawatan adalah dasar dalam pemikiran atau alasan ilmiah yang mendasari ditetapkannya rencana tindakan keperawatan.

\section{KESIMPULAN}

Perencanan adalah pengembangan strategi desain untuk mencegah, mengurangi, dan mengatasi masalahmasalah yang diidentifikasi dalam diagnosis keperawatan. Adapun tujuan dari perencanaan keperawatan terdiri dari 2 yaitu : 1. Tujuan administrasi, administrative mengidentifikasi focus keperawatan. 2.Tujua klinik, merupakan penunjuk dalam pelaksanaan tindakan keperawatan. Adapun kegiatan dalam tahap perencanaan : 1.Menentukan prioritas masalah keperawatan;. 2. Menetapakan tujuan dan kriteria hasil;. 3.Menetapkan kriteria hasil;. 4. Mermuskan rencana tindakan keperawatan;. 5. Menetapkan rasional rencana tindakan keperawatan.

\section{SARAN}

Setiap perawat harus memahami dengan sungguh konsep-konsep perencanaan yang meliputi penngertian, tujuan, keuntungan/kerugian, ciri-ciri perencanaan, dan kriteria-kriteria perencanaan yang efektif. Sebagai aplikasinya perlu dipahami pula perencanaan program dalam keperawatan/kesehatan dan perencanaan kebutuhan tenaga perawatan di Rumah Sakit.

\section{DAFTAR PUSTAKA}

Allen, C. V. (1998). Memahami Proses Keperawatan. Jakarta. EGC.

Asmadi. (2008). Konsep Dasar Keperawatan. Jakarta. EGC. 
Proses Dan Praktik Edisi 4. Jakarta :

Budiono \& Sumirah,B,P.(2016).

EGC.

Konsep Dasar Keperawatan (Ed 2).

Jakarta. Bumi Medika.

Potter \& Perry. ( 2010). Fundamental

Of Nursing : Edisi 7. Jakarta : EGC.

Dermawan, Deden. (2012). Proses

Keperawatan : Penerapan Konsep Dan

Rohma, N \& Wahid, S. (2009). Proses

Kerangka Kerja. Yogyakarta : Gosyen

Keperawattan. Arruz Media.

Publishing.

Deswani. (2009). Proses Keperawatan

Roper, Nancy. (1996). Prinsip-Prinsip dan Berpikir Kritis. Jakarta : Salemba Medika.

Keperawatan. Yogyakarta : Andi Yayasan Essentia Medica.

Simamora, R. H. (2009). Dokumentasi

Doengens, M. E., Mary, F. M \& Alice, keperawatan. Jamber University Press.

C. G. (1999). Rencana Asuhan

Keperawatan ed 3. Jakarta. EGC.

Simamora, R. H. ( 2010). Komunikasi

Dalam Keperawatan. Jamber

Haryanto. (2007). Konsep Dasar University Press.

Keperawatan Dengan Peemetaan

Konsep. Jakarta : Salemba Medika.

Simamora, R. H. (2008). Peran Manajemen Pembinaan Etika Perawat

Hidayat, A. Aziz Alimut. (2004). Pelaksanan Dalam Peningkatan Kualitas Pengantar Konsep Dasar Keperawatan. Jakarta. Salemba Medika. Pelayanan Asuhan Keperawatan. Jurnal IKESMA.

Lismidar,H.(1990).Proses

Tarwoto \& Wartonah. (2012).

Keperawatan. Jakarta : Universitas

Indonesi.

Kebutuhan Dasar Manusia Dan Proses Keperawatan. Jakarta : Salemba Medika.

Potter \& Perry. (2005). Buku Ajar Fundamental Keperawatan Konsep 
